\title{
Komunikasi dalam Musyawarah (Tinjauan Konsep Asyura dalam Islam)
}

\author{
Oleh: Tsalis Rifa'i. \\ Alumni Universitas Muhammadiyah Malang \\ (E-mail: tsalis_rifa'i@yahoo.com)
}

\begin{abstract}
Abstrak
Al Qur'an sebagai wahyu dan teks memiliki pesan-pesan yang diperuntukan bagi manusia. Dimana pesan-pesan tersebut memuat nilai sebagai petunjuk jalan hidup bagi manusia. Salah satu nilai yang terkandung dalam Al-Qur'an tersebut adalah musyawarah atau syura. musyawarah berarti perbuatan aktif yang tidak berhenti pada batas-batas sukarela dalam berpendapat, melainkan meningkat dari sukarela menjadi upaya perbuatan mengemukakan pendapat sebaik-baiknya. Tulisan ini bermaksud memaparkan mengenai konsep musyawarah dalam konteks sosial politik dan budaya masyarakat. Hasilnya adalah, Pertama, musyawarah sebagai kesetiakawanan, kekuatan serta kemerdekaan individu dan hak-hak mereka sebagai manusia. Kedua, musyawarah dapat dikatakan sebagai instrument dakwah apabila musyawarah dapat menjadi tempat memuliakan dan membimbing seseorang menuju arah yang lebih baik. Yang ketiga adalah, musyawarah sebagai kaidah sosial. Keempat adalah musyawarah sebagai khilafah berikut hak-haknya yang fitri.
\end{abstract}

Kata Kunci: Syura, Komunikasi, Dakwah dalam Musyawarah

\section{A. Latar Belakang}

\section{Musyawarah}

Secara bahasa kata asy syura diambil dari kata kerja syawara yang berarti menampakkan sesuatu atau mengeluarkan madu dari sarang lebah. ${ }^{1}$ Sedangkan kata musyawarah diambil dari bahasa Arab, yaitu syura yang diserap ke dalam bahasa Indonesia yang mengandung arti berunding dan berembuk. ${ }^{2}$ Dalam kamus Arabic English Dictionary, syura bermakna perundingan atau konsultasi. ${ }^{3}$ Jadi secara bahasa musyawarah adalah mengeluarkan pendapat, berembuk, konsultasi dengan orang lain.

Sedangkan secara terminologi musyawarah berarti perbuatan aktif yang tidak berhenti pada batas-batas sukarela dalam berpendapat, melainkan meningkat dari sukarela menjadi upaya perbuatan mengemukakan pendapat sebaik-baiknya. ${ }^{4}$

\footnotetext{
${ }^{1}$ Waryono Abdul Ghafur, Tafsir Sosial, (Yogyakarta: eLSAK Press, 2005), hlm. 153.

2 Tim Penyusun Kamus Pusat, Pembinaan dan Pengembangan Bahasa, Kamus Besar Bahasa Indonesia, (Jakarta: Balai Pustaka, 1995), hlm. 677.

${ }^{3}$ JM. Cowan, Arabic English Dictionary, (New York: Spoken Language Sevies, 1976), hlm. 492

${ }^{4}$ Muhammad Imaroh, Perang Terminologi Islam Versus Barat, terj. Musthalah Mawfur, (Jakarta: Robbani Press,1998), hlm. 171.
} 
Diterbitkan oleh Fakultas Sastra dan Budaya

Universitas Ahmad Dahlan Yogyakarta

Sedangkan menurut Abdul Haris musyawarah dalam arti luas dan umum adalah sikap bentuk tukar pendapat tentang semua obyek dan mengenai setiap ketetapan yang mengeluarkannya dan karakter dari sebuah ketetapan itu. ${ }^{5}$

Didalam penelitian dikenal adanya subyek musyawarah dan obyek musyawarah. Subyek musyawarah adalah seseorang yang melakukan musyawarah atau lebih tepatnya disebut dengan pelaku musyawarah. Adapun obyek musyawarah adalah materi atau isi yang dibahas dalam musyawarah atau lebih tepatnya disebut dengan masalah-masalah yang dimusyawarahkan.

\section{Komunikasi dalam Musyawarah}

a. Pengertian Komunikasi

Pengertian komunikasi secara bahasa, berasaldari bahasa latin "communicatio" dan perkataan sumbernya dari kata "communis" yang artinya sama, pengertian sama di sini adalah sama makna. ${ }^{6}$

Komuníkasi berlangsung dengan baik apabila ada kesamaan makna antara komunikan dengan komunikator, bisa dikatakan bahwa aseorang yang berkomunikasi mengharapkan agar orang lain ikut berpartisipasi dan bertindak dengan tujuan, harapan atau isi pesan yang disampaikan. Begitu juga dalam organisasi, komunikasi organisasi akan berlangsung dengan baik jika para peserta mentaati nilai-nilai sebagaimana termuat dalam teks Al Qur'an.

Sedang pengertian komunikasi secara terminologi menurut Warren Weaver bahwa komunikasi adalah keseluruhan suatu prosedur dengan suatu pikiran yang mempengaruhi pikiran yang lainnya. ${ }^{7}$

Menurut Onong Uchyana Effendi:

Komunikasi adalah proses penyampaian pesan oleh seseorang kepada orang lain untuk memberikan atau merubah sikap, pendapat atau perilaku, baik langsung melalui lesan atau tidak langsung melalui media. ${ }^{8}$

Sedang menurut Toto Tasmara memberikan definisi komunikasi sebagai berikut:

Komunikasi adalah proses pengoperan lambang yang berarti,dengan tujuan mempengaruhi sikap atau tingkah laku orang lain agar bertindak dengan sikap tingkah laku yang diharapkan. ${ }^{9}$

Dari beberapa pengertian yang telah dikemukakan di atas dapat ditarik kesimpulan bahwa komunikasi melibatkan banyak orang dimana seorang banyak menggunakan lambang-lambang baik dengan bahasa, gambar dan lain sebagainya. Dalam penyampaian

\footnotetext{
${ }^{5}$ Abdul Haris, Konsep Syura dalam Al Qur'an, ......1999, hlm. 25

6 Onong Uchyana Effendi, Ilmu Komunikosi: Teori don Praktek, (Bandung: RT. Remaja Rosda Karya, 2005), hlm. 11

Ton Kertapati, Dasar-Dasar Publisistik, (Jakarta: Percetakan Bina Aksara 1980), hlm. 100

${ }_{9}^{8}$ Onong Uchyana Effendi, Op. Cit., hlm. 6

${ }^{9}$ Toto Tasmara, Komunikasi Dakwah, (Jakarta: CV. Gaya Madia Pratama, 1987), hlm. 8
} 
pesan ketika musyawarah tidak lepas dari teori yang berhubungan dengan komunikasi, Baik yang berkaitan dengan komunikator (communicator), pesan (message), media (media), komunikan (communicant) dan efek (effect). ${ }^{10}$

Dalam konteks ini, komunikasi organisasi dalam budaya musyawarah akan berjalan lebih konstruktif dan efektif jika memadukan antara pesan dengan proses penyampaian pesan sesuai dengan nilai-nilai teks dalam Al Qur'an.

b. Jenis Komunikasi dalam Musyawarah

Komunikasi dalam musyawarah terdapat beberapa komponen yang penting, komponen tersebut tidak dapat dipisahkan antara satu dengan yang lainnya. Komponen tersebut adalah: Komunikasi kelompok dan komunikasi lesan sebagai media yang digunakan dalam bermusyawarah.

Komunikasi kelompok (group communication) adalah komunikasi yang berlangsung antara seorang komunikator dengan sekelompok orang yang jumlahnya lebih dari satu. Sekelompok orang tersebut bisa berjumlah sedikit atau banyak, kalau sedikit disebut komunikasi kelompok kecil (small group communication), sedangkan bila jumlahnya banyak disebut komunikasi kelompok besar (large group communication). ${ }^{11}$

c. Etika Komunikasi Dalam Musyawarah

Andersen mendefinisikan etika adalah suatu studi tentang nilai-nilai dan landasannya bagi penerapannya yang menyangkut bagaimana itu kebaikan dan bagaimana itu keburukan serta dilakukan dengan sengaja dan menyadarinya ketika perbuatan itu dilakukan. ${ }^{12}$

Jadi etika komunikasi dalam musyawarah adalah nilai-nilai yang mencakup sikap, opini, dan perílaku atau perbuatan seseorang secara sadar untuk menyampaikan pesan dalam musyawarah. Komponen-komponen etika dalam komunikasi adalah: competence (kemampuan atau kewenangan), integrity (kejujuran), dan good will (tenggangrasa). ${ }^{13}$

Adapun faktor-faktor pendukung etika dalam komunikasi adalah:

1) Persíapan (preparation), yaitu mempersiapkan baik bahan, sikap, psikologis ketika akan berbicara. Hal ini penting agar penguasaan materi dan proses komunikasi yang dijalani bisa berjalan dengan lancar.

2) Kesungguhan (seriousness), sikap yang sungguh-sungguh dalam berkomunikasi akan menimbulkan kepercayaan dari para komunikan.

3) Ketulusan (sincerity), sikap yang tulus dan jujur dari seorang komunikator akan menunjukkan reputasi sehingga akan menimbulkan kepercayaan.

4) Percaya diri (confidence), sikap percaya diri pada diri seorang komunikator akan berakibat pada penguasaan diri dan audience secara sempurna, sehingga psikologispun akan terdorong stabil.

\footnotetext{
${ }^{10}$ Onong Uchyana Effendi, Op. Cit. hlm. 6

${ }^{11}$ Onong Uchyana Effendi, Ilmu, Teori dan Filsafat Komunikasi, (Bandung: PT. Citra Aditya Bakti, 2000), hlm. 75

12 Ibid,.hlm. 384-386

${ }^{13}$ Ibid., hlm. 353
} 
Diterbitkan oleh Fakultas Sastra dan Budaya

Universitas Ahmad Dahlan Yogyakarta

5) Ketenangan (poise), sikap yang tenang akan membawa psikologis audience untuk selalu mengikuti dan memperhatikan pesan yang disampaikan. Dan dalam ketenangan ada dua faktor yang mendukung yaitu: keramahan dan kesederhanaan. Kedua-duanya akan menambah simpatik dari para komunikan. $^{14}$

\section{Dakwah dalam Musyawarah}

Dakwah dalam kata lain dapat disebut dengan amar ma'ruf nahimunkar atau mengajak pada kebaikan dan mencegah dari kemungkaran. Menurut pernyataan Syekh Muhammad Abduh sebagaimana dikutip oleh Taufiq Asy Syawi memberi pernyataan bahwa ayat-ayat Al Qur'an mengenai amar ma'ruf nahi munkar adalah dasar wajibnya musyawarah dan komitmen terhadapnya. Hal ini merupakan jawaban yang tegas bagi orang-orang yang membantahnya. Karena amar ma'ruf nahimunkar dengan segala universalnya mewajibkan seluruh individu agar mewakili jamaah dalam memerintah dan melarang sesuatu yang harus dítetapi. Dan mungkin lebih dari itu, hal ini mewajibkan kepada mereka untuk mengambil tindakan praktis dalam bentuk perintah atau larangan untuk mencegah kemungkaran dan menetapi kebaikan. ${ }^{15}$

Adapun yang dimaksud dengan dakwah dalam musyawarah adalah nilai-nilai apa saja yang terkandung dalam musyawarah sehingga dapat dikategorikan sebagai sebuah proses untuk ber'amar ma'ruf nahimunkar.

Sebagaimana telah disampaikan oleh DR. Taufiq Asy Syawi bahwa instrument dakwah dalam musyawarah meliputi: Pertama, musyawarah sebagai kesetiakawanan, kekuatan serta kemerdekaan individu dan hak-hak mereka sebagai manusia. Ini adalah arti musyawarah dalam bentuk universal dimana eksistensi orang banyak, kemudian hak dan tanggungjawabnya diambil dari seluruh individu sebagai bagian dari solidaritas seluruh individu tersebut. Dari konteks ini dapat digarisbawahi bahwa kepentingan orang banyak harus lebih diutamakan dari pada kepentingan individu. ${ }^{16}$

Kedua, musyawarah dapat dikatakan sebagai instrument dakwah apabila musyawarah dapat menjadi tempat memuliakan dan membimbing seseorang menuju arah yang lebih baik. Ketika manusia bebas melalui jalan yang dipersiapkan oleh syariat untuk memerdekakan bangsa dari cengkraman berbagai faktor material, dan juga dapat membebaskannya dari pengaruh aneka teori dan filsafat yang membelenggu mereka dalam mengatur urusannya sendiri dan dalam menggunakan haknya dalam menjalankan semua urusan itu sehingga memperoleh kemerdekaan secara sempurna, disitulah letak musyawarah sebagai pemuliaan dan bimbingan. ${ }^{17}$

Yang ketiga adalah, musyawarah sebagai kaidah sosial. Dapat dikatakan bahwa musyawarah sebagai kaidah sosial apabila musyawarah tidak menjadi saka guru pemerintahan yang akan membatasi kekuasaan para penguasa, tetapi yang dapat menjadi

\footnotetext{
${ }^{14}$ Ibid., hlm. 354-357

${ }^{15}$ Taufiq Asy Syawi, Syura Bukan Demokrasi, terj. Zainudin Z.S. (Jakarta: Gema Insani Press, 1997), hlm. 77-79

${ }^{16}$ Ibid., hlm. 16

${ }^{17}$ Ibid., hlm. 28
} 
tiang tegaknya kemerdekaan individu dan hak-hak bangsa dalam kesetiakawanan masyarakat dalam segi tatanan sosial, politik, ekonomi dan masalah-masalah kemasyarakatan yang lainnya. ${ }^{18}$

Keempat adalah musyawarah sebagai khilafah berikut hak-haknya yang fitri. Maksudnya adalah dalam tatanan kehidupan berbangsa dan bernegara musyawarah harus menjadi fondasi utamanya, dimana disitu ada umat yang mengharapkan sisi humanis menyadari setiap tatanan sosial yang berlaku. Olehkarena itu, fiqhul khilafah dan sistem pemerintahan harus kembali pada prinsip musyawarah. Artinya kebebasan yang diberikan oleh Allah kepada manusia tidak terbatas pada individu-individu saja tapi juga memberi kebebasan kepada jama'ah dan umat yang dewasa. ${ }^{19}$

Kemudian musyawarah dapat dikatakan menjadi instrument dakwah apabila musyawarah dapat fondasi HAM dan dapat menjalin kerjasama yang baik dan halal dalam mencari materi. Musyawarah sebagai teori umum dimulai dari hak asasi manusia dan kebebasannya serta kekuasan umat dan kedaulatannya. Karena penekanan HAM dalam syariat tidak terbatas pada kebebasan pribadi saja tetapi juga menetapkan dalam hal yang bersifat jama'ah. Diantaranya adalah hak dalam penggunaan harta dan jama'ah sebagai wujud kesetiakawanan sosial yang mengharuskan kerja sama. ${ }^{20}$

Dan yang terakhir adalah musyawarah dapat membangkitkan semangat untuk saling menguatkan tali persatuan dan kesatuan. Dalam kenyataan mayoritas negaranegara Islam yang masih berkembang, terbelakang dan tertinggal dari segi ekonomi, iptek maupun sumber daya manusianya, merupakan hal yang wajar apabila mayoritas rakyatnya mudah tergiur dengan gaya hidup yang hedonisme. Sehingga dengan gaya hidup tersebut umat akan semakin meninggalkan agama dan kultur yang telah ada sejak nenek moyang. Dengan adanya musyawarah diharapkanakan membawa persatuan bagi umat karena berbeda dalam mensikapi budaya hedonisme tersebut. ${ }^{21}$

\section{B. Urgensi Komunikasi Organisasi dengan Budaya Musyawarah}

\section{Dalam Kehidupan Bermasyarakat}

Menurut Thomas Shepard penerbit majalah Look $^{22}$, pemilihan tema seksualitas dalam iklan merupakan upaya keisengan yang dilakukan oleh pembuat iklan sebagai salah satu tindakan agar dapat merebut perhatian konsumen untuk melirik produk mereka. Selain itu juga dengan tema tersebut mampu menimbulkan kesadaran di benak penonton terhadap iklan mereka, bila diposisikan/dibandingkan dengan iklan-iklan yang lain. Hal ini muncul sebagai salah satu bentuk inovasi dari pembuat iklan yang menyadari bahwa manusia (dalam hal ini konsumen) memiliki keterbatasan dalam mengingat semua yang ada dan yang pernah dialami oleh manusia.

\footnotetext{
${ }^{18}$ Ibid., hlm. 32

${ }^{19}$ Ibid., hlm. 41

${ }^{20}$ Ibid., hlm. 43

${ }^{21}$ Ibid., hlm. 46

${ }^{22}$ Ibid., hal. 11.
} 
Diterbitkan oleh Fakultas Sastra dan Budaya

Universitas Ahmad Dahlan Yogyakarta

Eksistensi musyawarah sering diaktualisasikan dalam bentuk lembaga atau institusi, di mana institusi tersebut bernaung para wakil-wakil rakyat yang dipilih secara langsung oleh rakyat dengan media partai politik. Institusi ini penting karena, pertama setiap masalah yang menyangkut hal-hal yang berhubungan dengan kepentingan hajat hidup orang banyak, baik berupa masalah kenegaraan atau masalah agama tidak bisa penyeleseiannya diserahkan langsung kepada seluruh warga, akan tetapi bisa diserahkan pada kelompok tertentu yang mewakili atau menggambarkan suatu umat. Kedua, tingkat kecakapan dan keahlian tiap-tiap warga masyarakat berbeda-beda, sehingga orang yang mempunyai kompetensi pada bidangnya yang berhak mewakili dalam musyawarah tersebut. Ketiga, pelaksanaan al-amr bi-al ma'rufwa al-nahy 'an al-munkar memerlukan lembaga pengaturan yang jelas agar kemaslahatan umat dapat diraih. ${ }^{23}$

Ilustrasi musyawarah di atas pernah dilaksanakan nabi sebagai pemimpin negara. Hal ini terbukti dengan adanya Piagam Madinah (mitsaq madinah), konstitusi tersebut ditulis nabi dan disetujuí oleh kelompok-kelompok masyarakat (Nasrani, Muslim, Yahudi). ${ }^{24}$ Piagam Madinah dijadikan alat oleh Rasulullah untuk menyatukan komunitas-komunitas yang ada di jazirah Arab pada saat itu. Rasulullah menyadari betapa plural dan majemuknya mulai dari bentuk kepercayaan, suku ataupun ras, sehingga diperlukan sebuah kesepakatan bersama agar kedamaian dan kehidupan bermasyarakat berjalan denganbaik tanpa ada kecurigaan.

Poin-poin yang menjadi isi dari Piagam Madinah adalah: Pertama, orang-orang Muhajirin dari suku Quraisy tetap berpegang pada adat istiadat lama dalam hal kebaikan. Kedua, orang-orang mukmin yang bertaqwa harus bersatu dalam menghadapi para pembangkang, pedzalim, pendosa, dan pihak yang mengobarkan permusuhan. Ketiga, orang-orang Yahudi yang mengikuti kami baginya pertolongan dan hak persamaan dalam muamalah. Keempat, bagi orang Yahudi agama mereka dan bagi orang mukmin agama mereka pula. Kelima, Peserta harus saling menolong dalam menghadapi orang-orang yang menyerang Yastrib. ${ }^{25}$

Musyawarah seperti yang dipaparkan di muka merupakan wahana yang ditampilkan oleh Al Qur'an untuk manusia guna memenuhi kebutuhan dan menyelesaikan permasalahan hidupnya. Ia merupakan bentuk tolong menolong antar sesama manusia, baik sebagai makhluk individu maupun mahluk sosial.

Tolong menolong erat kaitannya dengan teori saling bergantung. Sikap ketergantungan manusia menunjukkan sifat kefakiran manusia itu, dan kefakiran melahirkan kebutuhan, baik kebutuhan materi maupun immateri. Menurut Peterson dan Plewman, kebutuhan manusia itu mencakup kebutuhan hidup (the desire to live), kebutuhan kepemílikan atas sesuatu (the desire for posession), kebutuhan diakui (the desire for recognation), dan kebutuhan berkuasa (the desire for power). Sedangkan menurut $\mathrm{Al}$ Ghazali kebutuhan itu mencakup kebutuhan berketurunan (procreation), kebutuhan

\footnotetext{
${ }^{23}$ Atang Abd. Hakim, dan Jaih Mubarok, Metodologi Studi Islam, cet. ke-5, Bandung: Rosda Karya, 2002.hlm.227

${ }^{24}$ Muhammad Hari Zamhari, Agama dan Negara; Analisis Kritis Pemikiran Nurcholish Majid, Jakarta: Raja Grafindo Persada, 2004. hlm. 13

25 Ahmad Syafi'i Ma'arif, Islam dan Politik; Teori Belah Dua Masa Demokrasi Terpimpin (1959-1965), (Jakarta: Gema Insani Press,1996), hlm. 143-147
} 
mempersiapkan kebutuhan fisik (preperation), kebutuhan akan perlindungan dan keamanan (protection). ${ }^{26}$

Dalam tanzil hakim $^{27}$ ada istilah khas yaitu syura atau musyawarah. Musyawarah di sini dapat diartikan sebagai praktek sekelompok manusia untuk terbebas dari otorítas apa pun selain dari otoritas pengetahuan, etika, dan estetika. Karena azas musyawarah adalah kebebasan dalam menyampaikan suatu pendapat.

Akan tetapi otoritas pengetahuan, etika dan estetika hanya bisa diterapkan pada dataran implementasi, sedangkan pada dataran substansi nilai ketauhiddan harus tetap diikutsertakan. Hal ini perlu untuk menghindarkan paham sekulerisme ${ }^{28}$ dalam pemerintahan. Sebuah dikotomi yang tidak tepat apabila kehídupan manusia dilepaskan dari otoritas agama, apalagi agama Islam, Karena jelas Islam adalah rahmatan líl'alamin, jadi Islam harus berkolaborasi dengan seluruh kegiatan dan perilaku manusia agar khalifah di bumi yang diembankan oleh sang Khalik tidak keluar dari jalurnya. Selain itu yang menjadi dasar penentangan terhadap Islam adalah penjelasan Muhammad, bahwa ia datang kedunia untuk menyempurnakan akhlaq manusia. Dan adanya ajaran tentang akhlaq yang baik dan benar hanya ada dalam risalah yang dibawa Muhammad dalam bentuk dien al-Islam.

Sehingga jelaslah kalau azas kehidupan dalam Islam adalah memberikan kebebasan dan kebolehan (ibahah) yang seluas-luasnya dalam bermusyawarah, maka manusia dapat mengekspresikan pendapatnya tanpa membutuhkan izin dari siapa pun. Karena pengekangan terhadap musyawarah akan menimbulkan kontradiksi internal, baik dari sisi etnis, politik maupun ekonomi yang akan berdampak pada akumulasi dan ledakan konflik sosíal. ${ }^{29}$

Tujuan musyawarah adalah untuk menggapai cita-cita perubahan agar lebih baik sebagaimana yang diidam-ídamkan oleh masyarakat. Dalam implementasinya diperlukan cara yang sesuai dengan situasi dan kondisi di mana masyarakat tersebut tinggal. Sebagaimana yang disampaikan oleh Kuntowijoyo dalam teori ilmu sosial profetiknya, diperlukan adanya humanisasi, liberasi dan transendensi.

Humanisasi adalah sikap untuk senantiasa memanusiakan manusia. Jadi merupakan sebuah kewajiban kalau manusia itu dianggap sebagai manusia seutuhnya dan bukan dianggap sebagai hewan. Karena fakta dalam musyawarah atau dalam persidangan masih banyak terjadi pelecehan terhadap orang lain. Sikap sepertí inilah yang harus

\footnotetext{
${ }^{26}$ Atang Abd.Hakim dan Jaih Mubarok,Op. Cit., hlm. 228

${ }^{27}$ Tanzil Hakim adalah sikap untuk mengambil rujukan pada ayat-ayat Al Qur'an yang mana ayat-ayat tersebut berkaitan dengan pokok bahasannya. Lihat dalam Muhammad Syahrur, Tirani Islam; Geneologi Masyarakat dan Negara,terj. Syaifudin Zufri Qudsi dan Badrus Samsul Fata, (Yogyakarta: LkiS, 1994, hlm kata-kata kunci.

${ }^{28}$ Sekulerisme adalah suatu idiologi yang mengajarkan praktek pemisahan antara agama dan institusi pemerintahan. Karena menurut paham ini agama dianggap sebagai masalah pribadi dan masalah subyektif yang hanya bermanfaat untuk memenuhi tuntutan kejiwaan. Sehingga harus dipisahkan dengan urusan ekonomi, politik, teknologi dan sosial budaya. Paham sekuler berkembang pertama kali di Eropa pada zaman Renaisans pada abad ke-16.Lihat, M. Amin Rais,Tauhid Sosial; Formula Menggempur Kesenjangan,(Bandung: Mizan, 1998), hlm. 76.

${ }^{29}$ Muhammad Syahrur,Op. Cit., hlm. 149
} 
Diterbitkan oleh Fakultas Sastra dan Budaya

Universitas Ahmad Dahlan Yogyakarta

dihíndari. Selanjutnya adalah liberasi, yaitu pembebasan bangsa dari kekejaman kemiskinan, keangkuhan teknologi dan pemerasan kelimpahan. Sudah merupakan kewajiban bagi anggota dewan dan pemerintah untuk tidak lagi membebani rakyat dengan hutang luar negeri, kemudian keberpihakan teknologi hanya untuk kepentingan eksploitasi harus dihentikan dan terakhir adalah memberikan keadilan dengan memberikan fasilitas negara tidak hanya untuk orang-orang yang mempunyai kekuasaan. Yang terakhir adalah transendensi yaitu menambahkan dimensi transenden dalam kebudayaan. Artinya adalah ketika melihat realitas kehidupan yang keras, maka solusi yang terbaik adalah membersihkan diri dengan mengingat kembali dimensi transendental dalam fitrah manusia yaitu mengembalikan dunia ini sebagai rahmatanlil 'alamin yang akhirnya bersentuhan kembali dengan kebesaranTuhan. ${ }^{30}$

Cara menerapkan konsep musyawarah seperti pada surah Ali Imran ayat 159, adalah dengan adanya kesepakatan tentang "Kolektif kolegial" atau semangat kebersamaan serta berpedoman pada norma-norma yang berlaku. Sistem kolegtif kolegial yang dimaksud adalah semangat kebersamaan dalam kultural, artinya diluar struktur kepengurusan. Hal ini dimaksudkan agar tidak ada jurang pemisah antara pemimpin dengan bawahan, atau antar pengurus. Semangat kebersamaan ini tercermin ketika orang lain sedang mendapat musibah atau sedang mendapat anugrah. Sahabat lain langsung akan memberikan simpatik berupa ucapan selamat ataupun ucapan belasungkawa. Adapun norma-norma yang berlaku dan yang telah disepakati ketika akan dilakukan musyawarah adalah selalu diawali dengan ucapan rasa syukur dan diakhiri dengan do'a. Hal ini dimaksudkan untuk selalu menjaga hubungan vertikal antara manusia selaku makhluk yang diciptakan dengan sang Khalik selaku pencipta.

Hambatan dalam menerapkan konsep musyawarah sebagaimana dalam surah Ali Imran adalah pertama, belum diketahui secara menyeluruh atau belum tersosialisasinya dengan baik bahwa ada sebuah konsep dalam Al Qur'an yang mengatur Musyawarah. Jadi langkah-langkah musyawarah yang mencakup bersikap lemah lembut, memaafkan, memohonkan ampun dan bertawakal banyak yang belum mengetahuinnya. Selama ini yang mereka lakukan adalah menjalankan budaya musyawarah dan menerapkan norma-norma yang berlaku. Yang antara lain budaya memanggil teman, budaya kultum sebelum musyawarah, budaya ucapan syukur dan diakhiri dengan sebuah do'a. Sedangkan untuk sikap bertawakal atas segala usaha yang telah dilakukan, itu semua bergantung pada diri mereka masing-masing hambatan yang kedua adalah sikap egois yang masih tinggi pada sebagian pengurus cabang. Sikap egois tersebut yang membuat suasana menjadi tidak kondusif dan tidak nyaman. Karena teman lain yang juga ikut musyawarah terkadang terbawa arus, sehingga mereka juga terbawa egois dengan terlebih dahulu timbul sikap jengkel (mangkel dalam bahasa jawa). Kalau sikap tersebut tumbul maka terkadang dan sering norma, nilai dan budaya yang selama ini melekat pada masyarakat menjadi tinggal nama karena dilanggar dan diacuhkan. Apalagi dalam musyawarah dalam lingkup yang besar yang serat dengan kepentingan. Disitu kesan egois sangat kentara karena yang bermain bukan lagi budaya, norma atau nilai tetapi yang bermain adalah kepentingan untuk

30 Kuntowijoyo, Paradigma Islam; Interpretasi Untuk Aksi, cet. ke-4, (Bandung: Mizan, 1993) hlm 288-289 
menduduki sebuah jabatan. Tawar menawar sebuah kedudukan dengan membangun koalisi sudah menjadi pemandangan yang biasa meskipun hannya dibelakang layar. Bahkan karena sikap egois yang berlebihan berimplikasi pada keadaan emosi peserta musyawarah tidak terkontrol, sehingga berakibat dead log dalam rapat.

Dalam setiap musyawarah tentunya berakhir dengan pangambilan keputusan sebagai bahan pijakan dalam melaksanakan program. Pengambilan keputusan terlebih dahulu dilakukan dengan mencari kemufakatan dalam setiap masalah. Dari sini semua aspek dipertimbangkan, baik berupa akibatnya ataupun menyangkut untung dan ruginnya. Karena terkadang tidak semua aspirasi setiap peserta musyawarah tidak tertampung, maka sering timbul kekecewaan Akan tetapi kekecewaan tersebut dapat diminimalisir dengan mengkaji ulang kelebihan dan kekurangan serta akibat dari setiap kebijakan yang diambil.

Apabila keputusan tidak dapat diambil dalam musyawarah mufakat langkah selanjutnnya adalah mengambil suara terbanyak untuk mencari keputusan. Akan tetapi mengambil keputusan dengan suara terbanyak ini dilakukan sangat jarang mengingat lebih bernilai diplomatis dan lebih bernuansa kekeluargaan bila diputuskan dengan jalan bermusyawarah. Biasannya suara terbanyak digunakan untuk mememilih jajaran pengurus baru, mengingat masalah ini sulit sekali bila dilakukan dengan musyawarah mufakat. Namun, apabila semua usaha telah diusahakan dan diupayakan tetapi masih belum juga menemukan solusi, maka jalan yang terbaik adalah dengan mengembalikan semua persoalan pada Al Qur'an dan Hadist. ${ }^{31}$

Adapun bentuk komunikasi yang dikembangkan dalam musyawarah adalah jenis komunikasi persuasif dan jenis komunikasi koordinatif, Komunikasi persuasif tercermin dari ajakan dan tawar menawar serta adu argumen tentang sebuah pendapat. Mulai dari cara penyampaian dan alasan yang dikemukakan dibuat semenarik mungkin agar orang lain mau menerima usul yang ditawarkan. Sedangkan komunikasi koordinatif diaktualisasikan dalam bentuk pemberian tugas oleh pimpinan terhadap anggota atau sebaliknnya, anggota menanyakan tugas yang akan diberikan oleh ketua kepadannya. Serta tidak menutup kemungkinan untuk melakukan pengecekkan serta pengawasan sejauh mana program dilaksanakan.

\section{Referensi}

Pustaka:

Abd. Hakim, Atang. dan Mubarok, Jaih. Metodologi Studi Islam, cet. ke-5, (Bandung: Rosda Karya, 2002).

Asy Syawi, Taufiq. Syura Bukan Demokrasi, terj. Zainudin Z.S. (Jakarta: Gema Insani Press, 1997)

Cowan, JM. Arabic English Dictionary, (New York: Spoken Language Sevies, 1976). Effendi, Onong Uchyana. Ilmu Komunikosi: Teori don Praktek, (Bandung: RT. Remaja Rosda Karya, 2005).

${ }^{31}$ Syekh Ibnu Taimiyah, Pedoman Islam Bernegara, terj. K.H. Firdaus AN.(Jakarta:Bulan Bintang, 1077). hlm. 261-266 
Diterbitkan oleh Fakultas Sastra dan Budaya

Universitas Ahmad Dahlan Yogyakarta

Effendi, Onong Uchyana. Ilmu, Teori dan Filsafat Komunikasi, (Bandung: PT. Citra Aditya Bakti, 2000). Ghafur, Waryono Abdul. Tafsir Sosial, (Yogyakarta: eLSAK Press, 2005). Haris, Abdul.

Konsep Syura dalam Al Qur'an, .......1999

Ibnu Taimiyah, Syekh, Pedoman Islam Bernegara, terj. K.H. Firdaus AN.(Jakarta:Bulan Bintang, 1077).

Imaroh, Muhammad. Perang Terminologi Islam Versus Barat, terj. Musthalah Mawfur, (Jakarta: Robbani Press, 1998).

Kertapati, Ton. Dasar-Dasar Publisistik, (Jakarta: Percetakan Bina Aksara 1980). Kuntowijoyo, Paradigma Islam; Interpretasi Untuk Aksi, cet. ke-4, (Bandung: Mizan, 1993)

Ma'arif, Ahmad Syafi'i. Islam dan Politik; Teori Belah Dua Masa Demokrasi Terpimpin (1959-1965), (Jakarta: Gema Insani Press,1996)

Rais,M. Amin. Tauhid Sosial; Formula Menggempur Kesenjangan,(Bandung: Mizan, 1998)

Syahrur, Muhammad. Tirani Islam; Geneologi Masyarakat dan Negara,terj. Syaifudin Zufri Qudsi dan Badrus Samsul Fata, (Yogyakarta: LkiS, 1994, hlm kata-kata kunci).

Tasmara, Toto. Komunikasi Dakwah, (Jakarta: CV. Gaya Madia Pratama, 1987).

Tim Penyusun Kamus Pusat, Pembinaan dan Pengembangan Bahasa, Kamus Besar Bahasa Indonesia, (Jakarta: Balai Pustaka, 1995)

Zamhari, Muhammad Hari. Agama dan Negara; Analisis Kritis Pemikiran Nurcholish Majid, (Jakarta: Raja Grafindo Persada, 2004). 